\title{
EFFECT OF GIVING FRASS HERMETIA ILLUCEN L. ON SOIL PHYSICAL CHEMICAL PROPERTIES, CHLOROPHYLL CONTENT AND YIELD OF UPLAND RICE (ORYZA SATIVA L.) ON ULTISOL SOIL
}

\author{
Reswita, Zozy Aneloi Noli, Resti Rahayu \\ University of Andalas, Mathematical and Natural Science Faculty, Biology \\ Department, Padang, West Sumatra, Indonesia \\ Email: reswitadharmasraya@gmail.com,zozynoli@sci.unand.ac.id \\ restirahayu@sci.unand.ac.id
}

\begin{tabular}{|c|c|}
\hline ARTICLE INFO & ABSTRACT \\
\hline $\begin{array}{l}\text { Received: } \\
\text { January, 26 } \\
2022 \\
\text { Revised: } \\
\text { February, 17th } \\
2022 \\
\text { Approved: } \\
\text { February, } 18^{\text {th }} \\
2022\end{array}$ & $\begin{array}{l}\text { Ultisol soils is a kind that experiences problems due to high } \\
\text { acidity and Al saturation, low nutrient, and organic matter } \\
\text { content, and are sensitive to erosion. Therefore, alternative } \\
\text { efforts need to be made to overcome this, one of which is } \\
\text { using Frass fertilizer from Black Soldier Fly fly larvae. Frass } \\
\text { is the result of bioconversion as a by-product of rearing BSF } \\
\text { larvae which contains a large number of nutrients that are } \\
\text { useful for plants and also to overcome the problem of } \\
\text { Ultisol soil. The purpose of this research knowing the effect } \\
\text { of giving BSF Frass and the extent to which Frass fertilizer } \\
\text { can replace the need for NPK fertilizer for upland rice (Oryza } \\
\text { sativa L.) on Ultisol soil. The experiment was arranged in a } \\
\text { factorial completely randomized design consisting of } 2 \\
\text { factors and } 3 \text { replications Factor A as the total dose; } \\
\text { control, } 10 \% \text { Frass, } 20 \% \text {, and } 30 \% \text { Frass, and Factor B as the } \\
\text { dose of NPK fertilizer: } 100 \% \text { positive control (according to } \\
\text { recommendations), } 75 \% \text {, 50\%, and } 25 \% \text {. The results showed } \\
\text { that the application of Frass can improve the physical and } \\
\text { chemical properties of Ultisol soil, and increase the grain } \\
\text { weight of } 100 \text { seeds. The combination of giving Frass } 30 \% \\
\text { with } 25 \% \text { NPK had a significant effect on increasing the } \\
\text { total chlorophyll content of upland rice leaves when } \\
\text { compared to giving Frass with doses of } 20 \% \text { and } 10 \% \text { with }\end{array}$ \\
\hline
\end{tabular}

Reswita, Zozy Aneloi Noli, Resti Rahayu. (2022). Effect of Giving

Frass Hermetia Illucen L. on Soil Physical Chemical Properties, Chlorophyll Content and Yield of Upland Rice (Oryza Sativa L.) On

How to cite: Ultisol Soil. Journal Eduvest. Vol 2(2): 335-346

E-ISSN:

Published by: $\quad$ https://greenpublisher.id/ 


\begin{aligned} \hline & $\begin{array}{l}\text { all combinations of NPK. However, it was not significantly } \\ \text { different when compared to the control combination which } \\ \text { received treatment with NPK as much as 100\% and 75\%.It } \\ \text { was concluded that the application of 30\% Frass combined } \\ \text { with 25\% NPK fertilizer had a significant effect on the } \\ \text { chlorophyll content of upland rice and had the potential to } \\ \text { reduce the use of chemical fertilizers by 25\%. }\end{array} \\$\hline KEYWORDS & Black Soldier Fly, Bioconversion, Frass, NPK, Ultisol \\ \hline CC) (i) (2) & $\begin{array}{l}\text { This work is licensed under a Creative Commons } \\ \text { Attribution-ShareAlike 4.0 International }\end{array}\end{aligned}$

\section{INTRODUCTION}

Rice production in Indonesia is generally managed as lowland rice and nonpaddy rice production (Fried et al., 2021). Lowland rice is rice that is produced from paddy fields while non-paddy rice is the result of upland rice grown on dry land. Until 2015 it was known that upland rice production only contributed about 5\% of the total national rice production (Pujawati, Suryanegara, \& Rudiastuti, 2020). Meanwhile, the dry land area in Indonesia reaches 108.8 million hectares, of which around 62.6 million hectares are suitable for agricultural cultivation areas (Rochayati, 2018).

One of the acid drylands that are widespread in Indonesia and have the potential as land for upland rice farming is Ultisol soil (Pujawati et al., 2020). Problems with Ultisol soil in its utilization are high acidity and $\mathrm{Al}$ saturation, low nutrient, and organic matter content, and sensitivity to erosion (HUTAHAEAN, 2022). These obstacles can be overcome by the application of technology such as liming, fertilization, and organic matter management (Gurmessa, 2021). However, giving lime if it is given in excess can be toxic to plants, while the application of inorganic fertilizers causes various negative impacts such as increased plant production costs, reduced soil fertility, and environmental problems (Prabowo \& Subantoro, 2018). Therefore, alternative efforts need to be made to reduce the use of inorganic fertilizers and replace them with organic fertilizers that are more environmentally friendly. One of them is using Frass fertilizer from Black Soldier Fly/BSF (Hermetia illucens L.) fly larvae.

Frass is the result of bioconversion as a by-product of rearing BSF larvae which contains a large number of nutrients that are useful for plants. Among the nutritional content of the Frass are total nitrogen of $2.1 \%$, total phosphorus of $1.16 \%$, total potassium of $0.17 \%$, total Ca of $0.19 \%$, and total $\mathrm{Mg}$ of $0.16 \%$ (Gurmessa, 2021). The use of BSF Frass as organic fertilizer is relatively a new concept in the agricultural system so it requires information about its performance related to the growth and development of agricultural crops, one of which can be observed through the chlorophyll content in plants. Because chlorophyll is part of the photosystem that functions to capture sunlight for the photosynthesis process (Porcar-Castell et al., 2021).

As for research related to testing the ability of BSF Frass as organic fertilizer, such as the research on Vigna unguiculata L. (Saputra et al., 2021), maize (Zea mays) (Alattar et al., 2016 and Beesigamukama et al., 2020), scallion (Zahn, 2017), ryegrass (Menino et al., 2021). However, research related to the effect of BSF Frass on upland rice chlorophyll levels is still limited. 
Based on the information above, it is necessary to do research on the effect of giving Frass Hermetia illucen L. on the physical and chemical properties of soil, chlorophyll content, and yield of upland rice (Oryza sativa L.) on Ultisol soil.

\section{RESEARCH METHOD}

This research was carried out from April to August 2021 at the Parak Karakah experimental garden, Padang City and the Plant Physiology Laboratory, Department of Biology, Faculty of Mathematics and Natural Sciences, Andalas University, Padang. The study used an experimental method arranged in a Factorial Completely Randomized Design (CRD) consisting of 2 factors and 3 replications.(Mukhlisah, Abustam, \& Maruddin, 2020) The first factor is the dose of Frass $(0,10 \%, 20 \%$, and $30 \%)$, while the second factor is the dose of NPK fertilizer $(100 \%, 75 \%, 50 \%$, and $25 \%)$.

Frass obtained from the State-Owned Enterprises (BUMNAG) Lubuk Alung Padang and West Java Maggot Manager. Meanwhile, the NPK fertilizer to be applied to the growing media was adjusted to the recommended dosage for upland rice, namely Urea $150 \mathrm{~kg} / \mathrm{ha}, \mathrm{SP}-3675 \mathrm{~kg} / \mathrm{ha}$, and $\mathrm{KCl} 50 \mathrm{~kg} / \mathrm{ha}$. Furthermore, analysis of macronutrient content in Frass and soil that has received additional Frass treatment was carried out.

The measurement of chlorophyll content was carried out in the vegetative phase, namely less than 60 days after planting using the Arnon method (1949). An analysis of chlorophyll content was carried out by grinding $0.5 \mathrm{~g}$ of young leaves with $50 \mathrm{ml}$ of $80 \%$ acetone in mortal for 5 minutes or until the leaf sample was smooth. Furthermore, the extract was centrifuged for 15 minutes at a speed of $3500 \mathrm{rpm}$ to separate the natant and supernatant. Then, the photosynthetic pigments (chlorophyll a, b and total chlorophyll) were analyzed using the spectrophotometer method. Optical Density (OD) of the extract was measured at wavelengths of 663 and $645 \mathrm{~nm}$. Chlorophyll content $(\mathrm{mg} / \mathrm{g})$ can be calculated by the following formula:

a. Chlorophyll $\mathrm{a}=[12.7(\mathrm{OD} 663)-2.69(\mathrm{OD} 645)] \mathrm{x} \mathrm{V} /(1000)(\mathrm{w})$

b. Chlorophyll $\mathrm{b}=[22.9(\mathrm{OD} 645)-4.68(\mathrm{OD} 663)] \times \mathrm{V} /(1000)(\mathrm{w})$

c. Total chlorophyll $=[20.2(\mathrm{OD} 645)+8.02(\mathrm{OD} 633)] \times \mathrm{V} /(1000)(\mathrm{w})$

Description:

OD : Optical Density of Spectrophotometer

$\mathrm{V} \quad$ : Volume of acetone used

W : Fresh weight of leaf sample used

Meanwhile, the observation of the weight of 100 grains of rice was carried out by weighing 100 grains of rice from each treatment.

Data analysis was carried out using the SPSS Statistics 24 IMB program on the content of chlorophyll a, b and total as well as grain weight of 100 seeds using analysis of variance (ANOVA). If the effect of the treatment is significantly different, it will be continued with the Duncan New Multiple Range Test (DNMRT) further test at the 5\% level.

\section{RESULT AND DISCUSSION}

\section{Analysis of Frass content and soil nutrient content}

The results of the analysis of Frass content and soil content that received Frass 
treatment are shown in Tables 1 and 2. The Nutrient analysis of Frass showed the presence of macroelements $\mathrm{N}, \mathrm{P}, \mathrm{K}$ that met the compost specification standard from domestic organic waste (SNI 19-7030-2004). While the results of the analysis of soil nutrients that received treatment with Frass showed that the treatment with Frass as much as $30 \%$ had a higher soil nutrient content than other dose treatments.

Table 1: Frass Content Analysis

\begin{tabular}{llll}
\hline NO & Parameter & Unit & Frass Content (\%) \\
\hline 1 & $\mathrm{pH}$ & $\%$ & 7.09 \\
2 & N-Total & $\%$ & 2,940 \\
3 & P-Total & $\%$ & 1,714 \\
4 & K-Total & $\%$ & 1.572 \\
5 & Na-Total & $\%$ & 1,482 \\
6 & Ca-Total & $\%$ & 1,404 \\
7 & Mg-Total & $\%$ & 1.002 \\
8 & S(Sulfur) & $\%$ & 0.207 \\
9 & C-Organic & $\%$ & 13,895 \\
10 & C/n & $\%$ & 4,726 \\
11 & Aluminum & $\mathrm{ppm}$ & 13.206 \\
\hline
\end{tabular}

Table 2: The results of the analysis of soil content after giving Frass

\begin{tabular}{lllllll}
\hline \multirow{2}{*}{ No } & $\begin{array}{l}\text { Elements of } \\
\text { Analysis }\end{array}$ & \multirow{2}{*}{ Unit } & \multicolumn{5}{l}{ Frass Dosage on Ultisol Soil (\%) } \\
\cline { 4 - 6 } & & $\mathbf{0}$ & $\mathbf{1 0}$ & $\mathbf{2 0}$ & $\mathbf{3 0}$ \\
\hline 1 & KA & $\%$ & 18.85 & 23.87 & 28,30 & 27.38 \\
& KKA & $\%$ & 1.18 & 1.23 & 1.28 & 1.27 \\
2 & pH & & 5.56 & 5.63 & 5.66 & 5.68 \\
3 & N-Total & $\%$ & 0.133 & 0.277 & 0.467 & 0.535 \\
4 & P-Available & ppm & 3,212 & 34,151 & 60,369 & 61,035 \\
5 & K,dd & me/100g & 0.269 & 0.392 & 0.379 & 0.370 \\
6 & Na,dd & me/100g & 0.255 & 0.575 & 0.414 & 0.412 \\
7 & Ca,dd & me/100g & 1.242 & 0.694 & 0.581 & 0.672 \\
8 & Mg, dd & me/100g & 0.749 & 0.857 & 1.047 & 1,201 \\
9 & Al,dd & me/100g & 8,038 & 14,227 & 13.0009 & 15.555 \\
10 & C-Organic & $\%$ & 0.566 & 5,898 & 10,396 & 10,531 \\
11 & B-Organic & $\%$ & 0.977 & 10,168 & 17,924 & 18,155 \\
12 & S(Sulfur) & ppm & 24,631 & 25,688 & 40,768 & 26,950 \\
13 & Porosity & & 62.13 & 63.12 & 68.59 & 68.91 \\
\hline
\end{tabular}

2. Chlorophyll Content Analysis

Based on the results of statistical analysis of the chlorophyll a, b and total chlorophyll content of upland rice plants, it is known that the dose of Frass and the combination of the dose of Frass with NPK fertilizer has a significantly different effect on the chlorophyll a, b and total chlorophyll content of upland rice plants. The chlorophyll content of upland rice applied with Frass and NPK fertilizer is shown in Tables 3, 4 and 5. 
Table 3. Content of chlorophyll a (mg/g) Upland rice plants applied with Frass and NPK Fertilizer Vegetative Phase

\begin{tabular}{|c|c|c|c|c|c|}
\hline \multirow{2}{*}{$\begin{array}{l}\text { Treatment } \\
\text { Frass Dose } \\
(\%)\end{array}$} & \multicolumn{4}{|l|}{ NPK Dose* } & \multirow{2}{*}{$\begin{array}{l}\text { Average } \\
\text { Factor A }\end{array}$} \\
\hline & $100 \%$ & $75 \%$ & $50 \%$ & $25 \%$ & \\
\hline 0 & $0.70 \pm 0.01 \mathrm{~h}$ & $0.65 \pm 0.02 \mathrm{gh}$ & $\begin{array}{l}0.61 \pm 0.03 \\
\text { efgh }\end{array}$ & $\begin{array}{l}0.55 \pm 0.02 \\
\text { cdefg }\end{array}$ & $\begin{array}{l}0.63 \pm 0.02 \\
C\end{array}$ \\
\hline 10 & $0.42 \pm 0.04 \mathrm{ab}$ & $0.46 \pm 0.03 \mathrm{bcd}$ & $\begin{array}{l}0.43 \pm 0.05 \\
\mathrm{abc}\end{array}$ & $\begin{array}{l}0.51 \pm 0.03 \\
\text { bcdef }\end{array}$ & $\begin{array}{l}0.45 \pm 0.04 \\
\text { A }\end{array}$ \\
\hline 20 & $\begin{array}{l}0.49 \pm 0.01 \\
\text { bcde }\end{array}$ & $\begin{array}{l}0.59 \pm 0.04 \\
\text { efgh }\end{array}$ & $\begin{array}{l}0.46 \pm 0.07 \\
\text { bcd }\end{array}$ & $0.33 \pm 0.03 \mathrm{a}$ & $\begin{array}{l}0.47 \pm 0.03 \\
\text { A }\end{array}$ \\
\hline 30 & $0.43 \pm 0.04 \mathrm{ab}$ & $\begin{array}{l}0.50 \pm 0.02 \\
\text { bcdef }\end{array}$ & $\begin{array}{l}0.57 \pm 0.02 \\
\text { defg }\end{array}$ & $0.61 \pm 0.01 \mathrm{fgh}$ & $\begin{array}{l}0.53 \pm 0.09 \\
\mathrm{~B}\end{array}$ \\
\hline $\begin{array}{l}\text { Average } \\
\text { factor B }\end{array}$ & $0.51 \pm 0.02 \mathrm{~A}$ & $0.55 \pm 0.03 \mathrm{~A}$ & $0.52 \pm 0.04 \mathrm{~A}$ & $0.50 \pm 0.02 \mathrm{~A}$ & \\
\hline $\begin{array}{l}\text { Descripti } \\
\text { on: }\end{array}$ & \multicolumn{5}{|c|}{$\begin{array}{l}\text { Factor } \mathrm{A} \text { and Factor } \mathrm{A} * \mathrm{~B} \text { were significantly different. } \\
\text { The numbers in each row and column followed by the same uppercase and } \\
\text { lowercase letters showed results that were not significantly different for } \\
\text { each single factor and combination factor at the } 5 \% \text { level of the DNMRT } \\
\text { test. }\end{array}$} \\
\hline
\end{tabular}

Table 4. Chlorophyll b content (mg/g) Upland rice plants applied with Frass and Vegetative Phase NPK Fertilizer

\begin{tabular}{|c|c|c|c|c|c|}
\hline \multirow{2}{*}{$\begin{array}{l}\text { Treatme } \\
\text { nt } \\
\text { Frass } \\
\text { Dose } \\
(\%)\end{array}$} & \multicolumn{4}{|l|}{ NPK Dose* } & \multirow{2}{*}{$\begin{array}{l}\text { Average } \\
\text { Factor A }\end{array}$} \\
\hline & $100 \%$ & $75 \%$ & $50 \%$ & $25 \%$ & \\
\hline 0 & $1.78 \pm 0.06 \mathrm{~g}$ & $1.53 \pm 0.08 \mathrm{fg}$ & $\begin{array}{l}1.38 \pm 0.15 \\
\text { def }\end{array}$ & $1.23 \pm 0.09 \mathrm{cdef}$ & $\begin{array}{l}1.48 \pm 0.09 \\
\mathrm{C}\end{array}$ \\
\hline 10 & $0.87 \pm 0.11 \mathrm{ab}$ & $\begin{array}{l}0.96 \pm 0.10 \\
a b c\end{array}$ & $\begin{array}{l}0.90 \pm 0.12 \\
\mathrm{abc}\end{array}$ & $1.12 \pm 0.06 \mathrm{bcd}$ & $\begin{array}{l}0.96 \pm 0.09 \\
\text { A }\end{array}$ \\
\hline 20 & $\begin{array}{l}1.05 \pm 0.04 \\
\text { bcd }\end{array}$ & $\begin{array}{l}1.35 \pm 0.09 \\
\text { def }\end{array}$ & $\begin{array}{l}1.04 \pm 0.19 \\
\text { bcd }\end{array}$ & $0.68 \pm 0.08 \mathrm{a}$ & $\begin{array}{l}1.03 \pm 0.10 \\
\mathrm{~A}\end{array}$ \\
\hline 30 & $\begin{array}{l}0.95 \pm 0.13 \\
a b c\end{array}$ & $\begin{array}{l}1.16 \pm 0.05 \\
\text { bcd }\end{array}$ & $\begin{array}{l}1.32 \pm 0.05 \\
\text { def }\end{array}$ & $1.48 \pm 0.04 \mathrm{efg}$ & $\begin{array}{l}1.23 \pm 0.06 \\
\text { B }\end{array}$ \\
\hline $\begin{array}{l}\text { Average } \\
\text { factor B }\end{array}$ & $1.16 \pm 0.08 \mathrm{~A}$ & $1.25 \pm 0.08 \mathrm{~A}$ & $1.16 \pm 0.12 \mathrm{~A}$ & $1.13 \pm 0.06 \mathrm{~A}$ & \\
\hline $\begin{array}{l}\text { Descriptio } \\
\text { n: }\end{array}$ & \multicolumn{5}{|c|}{$\begin{array}{l}\text { Factor } \mathrm{A} \text { and Factor } \mathrm{A} * \mathrm{~B} \text { are significantly different, Factor } \mathrm{B} \text { is not } \\
\text { significantly different } \\
\text { The numbers in each row and column followed by the same uppercase and } \\
\text { lowercase letters showed results that were not significantly different for } \\
\text { each single factor and interaction factor at the } 5 \% \text { level of the DNMRT test. } \\
*=\text { From the recommended dose }\end{array}$} \\
\hline
\end{tabular}


Table 5. Total chlorophyll content $(\mathrm{mg} / \mathrm{g})$ vegetative phase Upland rice plants applied with Frass and NPK Fertilizer Vegetative Phase

\begin{tabular}{|c|c|c|c|c|c|}
\hline \multirow{2}{*}{$\begin{array}{l}\text { Treatme } \\
\mathrm{nt} \\
\text { Frass } \\
\text { Dose } \\
(\%)\end{array}$} & \multicolumn{4}{|c|}{ NPK Dose* } & \multirow{2}{*}{$\begin{array}{l}\text { Average } \\
\text { Factor A }\end{array}$} \\
\hline & $100 \%$ & $75 \%$ & $50 \%$ & $25 \%$ & \\
\hline 0 & $\begin{array}{l}2.48 \pm 0.07 \\
\mathrm{~h}\end{array}$ & $2.18 \pm 0.10 \mathrm{gh}$ & $1.99 \pm 0.18 \mathrm{efg}$ & $\begin{array}{l}1.78 \pm 0.12 \\
\text { cdefg }\end{array}$ & $\begin{array}{l}2.11 \pm 0.11 \\
\mathrm{C}\end{array}$ \\
\hline 10 & $\begin{array}{l}1.29 \pm 0.15 \\
\mathrm{ab}\end{array}$ & $1.42 \pm 0.13 \mathrm{abc}$ & $1.34 \pm 0.17 \mathrm{abc}$ & $\begin{array}{l}1.63 \pm 0.09 \\
\text { bcde }\end{array}$ & $\begin{array}{l}1.42 \pm 0.13 \\
\text { A }\end{array}$ \\
\hline 20 & $\begin{array}{l}1.54 \pm 0.05 \\
\text { bcde }\end{array}$ & $\begin{array}{l}1.95 \pm 0.13 \\
\text { defg }\end{array}$ & $1.51 \pm 0.07 \mathrm{bcd}$ & $1.02 \pm 0.12 \mathrm{a}$ & $\begin{array}{l}1.50 \pm 0.09 \\
\mathrm{~A}\end{array}$ \\
\hline 30 & $\begin{array}{l}1.38 \pm 0.17 \\
\mathrm{abc}\end{array}$ & $\begin{array}{l}1.67 \pm 0.08 \\
\text { bcdef }\end{array}$ & $1.89 \pm 0.07 \mathrm{defg}$ & $2.10 \pm 0.04 \mathrm{fgh}$ & $\begin{array}{l}1.76 \pm 0.09 \\
\text { B }\end{array}$ \\
\hline $\begin{array}{l}\text { Average } \\
\text { factor B }\end{array}$ & $\begin{array}{l}1.67 \pm 0.11 \\
\text { A }\end{array}$ & $1.80 \pm 0.11 \mathrm{~A}$ & $1.68 \pm 0.12 \mathrm{~A}$ & $1.63 \pm 0.09 \mathrm{~A}$ & \\
\hline $\begin{array}{l}\text { Descripti } \\
\text { on: }\end{array}$ & \multicolumn{5}{|c|}{$\begin{array}{l}\text { Factor } \mathrm{A} \text { and Factor } \mathrm{A} * \mathrm{~B} \text { were significantly different, Factor } \mathrm{B} \text { was not } \\
\text { significantly different. } \\
\text { The numbers in each row and column followed by the same uppercase and } \\
\text { lowercase letters showed results that were not significantly different for } \\
\text { every single factor and combination factor at the } 5 \% \text { level of the DNMRT } \\
\text { test. } \\
*=\text { From the recommended dose }\end{array}$} \\
\hline
\end{tabular}

Based on Tables 3, 4, and 5, it is known that the treatment with Frass showed a significantly different effect on the chlorophyll a, b and total chlorophyll content of upland rice plants in Ultisol soil. The higher the dose of Frass, the chlorophyll content of upland rice plants also increased but was not higher than the control. While the treatment with NPK fertilizer showed no significant effect for all treatment doses. While the combination treatment of Frass with NPK fertilizer showed that the combination treatment of $30 \%$ Frass with $25 \%$ NPK was not significantly different from the control treatment with $100 \%$ and $75 \%$ NPK but was significantly different from other dose treatments. 
Table 6. Grain Weight of 100 Seeds (g) Upland rice plants applied with Frass and NPK Fertilizer

\begin{tabular}{|c|c|c|c|c|c|}
\hline \multirow{2}{*}{$\begin{array}{l}\text { Treatment } \\
\text { Frass } \\
\text { Dose } \\
(\%)\end{array}$} & \multicolumn{4}{|l|}{ NPK Dose* } & \multirow{2}{*}{$\begin{array}{l}\text { Average } \\
\text { Factor A }\end{array}$} \\
\hline & $100 \%$ & $75 \%$ & $50 \%$ & $25 \%$ & \\
\hline 0 & $\begin{array}{l}2.43 \pm 0.04 \\
\text { abcd }\end{array}$ & $2.34 \pm 0.04 \mathrm{ab}$ & $\begin{array}{l}2.37 \pm 0.05 \\
\mathrm{abc}\end{array}$ & $\begin{array}{l}2.35 \pm 0.04 \\
a b c\end{array}$ & $\begin{array}{l}2.37 \pm 0.04 \\
\text { A }\end{array}$ \\
\hline 10 & $2.31 \pm 0.06 \mathrm{a}$ & $2.34 \pm 0.03 \mathrm{ab}$ & $2.33 \pm 0.02 \mathrm{ab}$ & $\begin{array}{l}2.35 \pm 0.03 \\
\mathrm{abc}\end{array}$ & $\begin{array}{l}2.33 \pm 0.03 \\
\mathrm{~A}\end{array}$ \\
\hline 20 & $\begin{array}{l}2.33 \pm 0.07 \\
\mathrm{ab}\end{array}$ & $\begin{array}{l}2.40 \pm 0.03 \\
\text { abcd }\end{array}$ & $\begin{array}{l}2.43 \pm 0.05 \\
\text { abcd }\end{array}$ & $2.34 \pm 0.05 \mathrm{ab}$ & $\begin{array}{l}2.37 \pm 0.05 \\
\mathrm{~A}\end{array}$ \\
\hline 30 & $\begin{array}{l}2.53 \pm 0.02 \\
\mathrm{~cd}\end{array}$ & $\begin{array}{l}2.44 \pm 0.02 \\
\text { abcd }\end{array}$ & $\begin{array}{l}2.51 \pm 0.08 \\
\text { bcd }\end{array}$ & $2.57 \pm 0.09 \mathrm{~d}$ & $\begin{array}{l}2.51 \pm 0.05 \\
\text { B }\end{array}$ \\
\hline $\begin{array}{l}\text { Average } \\
\text { factor B }\end{array}$ & $\begin{array}{l}2.40 \pm 0.048 \\
\mathrm{~A}\end{array}$ & $2.38 \pm 0.03 \mathrm{~A}$ & $2.41 \pm 0.05 \mathrm{~A}$ & $2.40 \pm 0.05 \mathrm{~A}$ & \\
\hline escription & \multicolumn{5}{|c|}{$\begin{array}{l}\text { Factor } \mathrm{A} \text { and Factor } \mathrm{A} * \mathrm{~B} \text { are significantly different, Factor } \mathrm{B} \text { is not } \\
\text { significantly different } \\
\text { The numbers in each row and column followed by the same uppercase } \\
\text { and lowercase letters showed results that were not significantly different } \\
\text { for every single factor and interaction factor at the } 5 \% \text { level of the } \\
\text { DNMRT test. } \\
*=\text { From the recommended dose }\end{array}$} \\
\hline
\end{tabular}

\section{Discussion}

1. The results of the analysis of the Frass content and soil content

The results of the analysis of the content of BSF fertilizer with several parameters including test results that meet the compost specifications from domestic organic waste, namely $\mathrm{pH}$, N-Total, P-Total, K-Total, Mg-Total, and C-Organic. Based on this, it can be seen that Frass (BSF fertilizer) has a high nutrient content and can support plant growth.

Based on the soil content before and after administration of Frass, the $\mathrm{pH}$ increased towards a neutral $\mathrm{pH}$ along with the increase in the dose of Frass. It is suspected that Frass is included in the category of humic acid. Humic acid contains hydroxyl and carboxyl functional groups with activities that can reduce the hydrolysis of hydrogen ions so as to increase soil $\mathrm{pH}$ (Winarso, et al., 2009). With the increasing content of humic acid, it will be able to increase the $\mathrm{pH}$ and availability of $\mathrm{P}$ in the soil (Ifansyah, Himmah, \& Pertiwi, 2021). Then the macronutrient content which includes N-Total, P-Total, KTotal, Mg-Total, and S increased along with the addition of Frass dose and the highest dose of 30\% Frass was given.SNI 19-7030-2004.

Based on research conducted by Yuniarti et al., (2019), organic fertilizer application has a significant effect on increasing levels of C-Organic, N-Total, C/N, N uptake, and yield of Black Rice (Oryza sativa L. indica). on Inceptisol from Jatinangor. It is known that the element $\mathrm{N}$ is an essential nutrient which is included in the macro nutrient which is needed in large quantities.(Sofyan, Sara, \& Machfud, 2019) The function of nitrogen is to improve plant vegetative growth and protein formation. The element $\mathrm{N}$ has an important role in the growth and development of all living tissues. In 
addition, organic fertilizers are also known to be able to improve soil structure by mineralizing organic matter which has an impact on the availability of macro and micro nutrients.

2. Response chlorophyll content against gift giving

In the treatment with Frass, there were differences in chlorophyll content, presumably due to the presence of different nutrients between the control and Frass treatment. Nutrients including $\mathrm{N}, \mathrm{P}, \mathrm{K}, \mathrm{Mg}$, and $\mathrm{S}$ play a role in the formation of plant chlorophyll. Based on Table 2, it can be seen that the presence of elements $\mathrm{N}, \mathrm{P}, \mathrm{K}, \mathrm{Mg}$ and $\mathrm{S}$ in Frass is $30 \%$ higher than other treatments. This is thought to be a factor that supports the increase in chlorophyll levels in the treatment with $30 \%$ Frass, which is higher than the $20 \%$ and $10 \%$ Frass treatment. However, the chlorophyll content in the $30 \%$ treatment was not higher than the control.(Sofyan et al., 2019) This is thought to be due to the presence of a higher aluminum element in Frass which is one of the factors that affect the chlorophyll content.(da Silva, de Mello Prado, Soares, de Almeida, \& dos Santos, 2021) The aluminum element in the Frass treatment was $30 \%$ higher, namely 15 , $555 \mathrm{me} / 100 \mathrm{~g}$ while the control is around $8.038 \mathrm{me} / 100 \mathrm{~g}$. The higher presence of the aluminum element is thought to affect the chlorophyll content of upland rice plants because the aluminum element can fix phosphorus so that phosphorus becomes insoluble and is not available in the soil (Bohn, et al., 2001). This is in line with the research by Karimaei and Poozesh (2016) which states that the presence of high Al elements can reduce the total chlorophyll content (chlorophyll a and chlorophyll b) in spinach plants in acid soils.

The chlorophyll content of plants is not only affected by the presence of N, P and $\mathrm{K}$ elements, but also by the presence of $\mathrm{Mg}$ elements.(Chrysargyris, Papakyriakou, Petropoulos, \& Tzortzakis, 2019) Magnesium is a component of chlorophyll which is needed for photosynthesis and protein synthesis. Magnesium as the central atom of the chlorophyll molecule acts in collecting photons in photosystem I (PS I) and photosystem II (PS II).(Sirohiwal, Neese, \& Pantazis, 2021) Mg deficiency can cause chlorosis and even necrosis as a form of decreased chlorophyll content, $\mathrm{CO} 2$ fixation, decreased carbon metabolism and electron transfer in photosynthesis. Because the element $\mathrm{Mg}$ plays a key role in utilizing light energy in the photosynthesis process (Marschner, 2002; Chaudhry et al., 2021; Farhat et al.,2014). From the results of soil nutrient analysis, in the treatment with $30 \%$ Frass the magnesium content was higher $(1,201 \mathrm{me} / 100 \mathrm{~g})$ compared to other treatments and controls $(0.749 \mathrm{me} / 100 \mathrm{~g})$. So it is suspected that although the $\mathrm{Al}$ content affects the availability of phosphorus in the growing media, the presence of higher $\mathrm{Mg}$ encourages the formation of chlorophyll in the 30\% treatment with Frass to increase compared to the $20 \%$ and $10 \%$ doses.

3. Response chlorophyll content against giving combination Frass with NPK

Based on Table 3 for the combination treatment using NPK fertilizer, the highest chlorophyll a content of upland rice plants was obtained, namely the $30 \%$ Frass treatment with 25\% NPK and treatment without Frass with $100 \%, 75 \%$ and $50 \%$ NPK. This is related to the presence of nitrogen in the Frass used, which shows that the nitrogen content of the Frass is quite high and is in accordance with the compost specifications from domestic organic waste. Supported by Wenno and Sinay's research (2019) on pakcoy plants treated with the addition of manure containing high nitrogen content combined with tofu waste was proven to increase chlorophyll a levels by $2.007 \mathrm{mg} / \mathrm{L}$. 
This shows that the nitrogen content plays an important role in increasing the levels of chlorophyll a.

Table 4 shows the effect of the combination of Frass and NPK on the content of chlorophyll $b$. The combination of treatment giving $30 \%$ Frass with $25 \%$ NPK showed no significant effect with the combination of control treatment with $100 \%$ and $75 \%$ NPK. Chlorophyll $b$ is in charge of capturing light waves with a wider range than chlorophyll a, which is limited in capturing light waves, but chlorophyll $\mathrm{b}$ functions as an antenna that collects light to be transferred to the reaction center. The formation of chlorophyll b also requires sufficient nitrogen elements. Research conducted by Wenno \& Sinay (2019) which proved that Brassica chinensis L. plants which were treated with manure with a higher nitrogen content,

4. Response grain weight 100 seeds against giving combination Frass with NPK

Giving Frass as much as 30\% showed a significantly different effect on grain weight of 100 upland rice seeds compared to lower doses and controls.(Momesso et al., 2020) This is because the addition of Frass to Ultisol soil can increase nutrient uptake, as can the use of organic fertilizers which can also increase nutrient uptake of N, P and K in rice plants in Yang et al., (2004) research. The use of organic fertilizers significantly increases the uptake of $\mathrm{N}, \mathrm{P}$ and $\mathrm{K}$ and facilitates the allocation and transfer of nutrients, especially $\mathrm{P}$ to the rice grains. This resulted in a significant increase in the weight of 1000 grains and grain yields. Based on the results of soil analysis (Table 2), 30\% Frass contains higher P nutrients, which is $61.035 \mathrm{ppm}$ higher than the $20 \%$ dose of Frass, $10 \%$ or without Frass. According to Nugroho (2016), increasing the phosphorus content in the soil can increase the weight of 1000 plant seeds. It is also supported by the results of research by Beesigamukama et al., (2021) which prove that in addition to having high N, $\mathrm{P}$ and $\mathrm{K}$ content, Frass fertilizer has the ability to increase the mineralization rate by 3-10 times and nitrification 2-4 times compared to ordinary fertilizers. and without fertilizer. In addition, giving Frass has the potential to increase the population of fungi and bacteria in the soil and reduce soil acidity. Siregar's research (2013) stated that the application of organic material in the form of straw compost and cow manure had a significant effect with treatment without organic matter on the dry weight of 1000 grains of rice. by increasing the phosphorus content in the soil, it can increase the weight of 1000 plant seeds. It is also supported by the research results of Beesigamukama et al., (2021) which prove that in addition to having high N, P and $\mathrm{K}$ content, Frass fertilizer has the ability to increase the mineralization rate by 3-10 times and nitrification 2-4 times compared to ordinary fertilizers. and without fertilizer. In addition, giving Frass has the potential to increase the population of fungi and bacteria in the soil and reduce soil acidity. Siregar's research (2013) stated that the application of organic material in the form of straw compost and cow manure had a significant effect with treatment without organic matter on the dry weight of 1000 grains of rice. by increasing the phosphorus content in the soil, it can increase the weight of 1000 plant seeds. It is also supported by the research results of Beesigamukama et al., (2021) which prove that in addition to having high N, P and K content, Frass fertilizer has the ability to increase the mineralization rate by $3-10$ times and nitrification 2-4 times compared to ordinary fertilizers. and without fertilizer. In addition, giving Frass has the potential to increase the population of fungi and bacteria in the soil and reduce soil acidity. Siregar's research (2013) stated that the application of organic material in the form of straw compost and cow manure had a significant effect 
with treatment without organic matter on the dry weight of 1000 grains of rice. It is also supported by the research results of Beesigamukama et al., (2021) which prove that in addition to having high $\mathrm{N}, \mathrm{P}$ and $\mathrm{K}$ content, Frass fertilizer has the ability to increase the mineralization rate by 3-10 times and nitrification 2-4 times compared to ordinary fertilizers. and without fertilizer. In addition, giving Frass has the potential to increase the population of fungi and bacteria in the soil and reduce soil acidity. Siregar's research (2013) stated that the application of organic material in the form of straw compost and cow manure had a significant effect with treatment without organic matter on the dry weight of 1000 grains of rice. It is also supported by the research results of Beesigamukama et al., (2021) which prove that in addition to having high $\mathrm{N}, \mathrm{P}$ and $\mathrm{K}$ content, Frass fertilizer has the ability to increase the mineralization rate by 3-10 times and nitrification 2-4 times compared to ordinary fertilizers. and without fertilizer. In addition, giving Frass has the potential to increase the population of fungi and bacteria in the soil and reduce soil acidity. Siregar's research (2013) stated that the application of organic material in the form of straw compost and cow manure had a significant effect with treatment without organic matter on the dry weight of 1000 grains of rice. Frass fertilizer has the ability to increase the mineralization rate by 3-10 times and nitrification 2-4 times compared to the application of ordinary fertilizer and without fertilizer. In addition, giving Frass has the potential to increase the population of fungi and bacteria in the soil and reduce soil acidity. Siregar's research (2013) stated that the application of organic material in the form of straw compost and cow manure had a significant effect with treatment without organic matter on the dry weight of 1000 grains of rice. Frass fertilizer has the ability to increase the mineralization rate by 3-10 times and nitrification 2-4 times compared to the application of ordinary fertilizer and without fertilizer. In addition, giving Frass has the potential to increase the population of fungi and bacteria in the soil and reduce soil acidity. Siregar's research (2013) stated that the application of organic material in the form of straw compost and cow manure had a significant effect with treatment without organic matter on the dry weight of 1000 grains of rice.

In the combination of using Frass with NPK fertilizer, the highest grain weight of 100 upland rice seeds was obtained, namely at $30 \%$ Frass with $25 \%$ NPK dose. At a dose of $30 \%$ Frass with a combination of $25 \%, 50 \%, 75 \%$ and $100 \%$ NPK, the results were not significantly different. So it can be stated that Frass plays a role in increasing the weight of 100 seeds of grain. This is thought to be due to the provision of Frass which plays a role in increasing soil fertility. Frass as a bioconversion product from BSF flies contains beneficial bacteria to complement the nutrient needs of the soil and provide a good supply and availability of nutrients to plants. In line with the opinion of Sarpong et al, (2019) that the high nitrogen content in Frass is a form of biochemical activity of BSF larvae and nitrifying bacteria secreted from the intestines of BSF larvae. It is supported by the research of Menino et al., (2020) that Frass fertilizer is able to increase dehydrogenase activity due to its higher $\mathrm{N}$ content. Dehydrogenase is an intracellular enzyme produced by microorganism cells. Dehydrogenase activity can be used as a parameter to determine general soil microbial activity. Dehydrogenase is considered a good measure of oxidative microbial metabolism in soil. The increasing number of Frass used is in line with the increase in soil microbial activity and dehydrogenase activity which affects plant productivity. Dehydrogenase activity can be used as a parameter to determine general soil microbial activity. Dehydrogenase is considered a good measure of oxidative microbial metabolism in soil. The increasing number of Frass used is in line with the increase in soil 
microbial activity and dehydrogenase activity which affects plant productivity. Dehydrogenase activity can be used as a parameter to determine general soil microbial activity. Dehydrogenase is considered a good measure of oxidative microbial metabolism in soil. The increasing number of Frass used is in line with the increase in soil microbial activity and dehydrogenase activity which affects plant productivity

\section{CONCLUSION}

Based on the results obtained, it can be concluded that Giving Frass as much as $30 \%$ combined with $25 \%$ NPK fertilizer has a significant effect on the chlorophyll content of upland rice and has the potential to reduce the use of chemical fertilizers by $25 \%$.

\section{REFERENCES}

Chrysargyris, Antonios, Papakyriakou, Eleftheria, Petropoulos, Spyridon A., \& Tzortzakis, Nikolaos. (2019). The combined and single effect of salinity and copper stress on growth and quality of Mentha spicata plants. Journal of Hazardous Materials, 368, 584-593.

da Silva, Edson Santos, de Mello Prado, Renato, Soares, Anelisa de Aquino Vidal Lacerda, de Almeida, Hilario Junior, \& dos Santos, Durvalina Maria M. (2021). Response of corn seedlings (Zea mays L.) to different concentrations of nitrogen in absence and presence of silicon. Silicon, 13(3), 813-818.

Fried, Oliver, Westphal, Catrin, Schellenberg, Jenny, Grescho, Volker, Kühn, Ingolf, Van Sinh, Nguyen, Settele, Josef, \& Bergmeier, Erwin. (2021). Vascular plant species diversity in Southeast Asian rice ecosystems is determined by climate and soil conditions as well as the proximity of non-paddy habitats. Agriculture, Ecosystems \& Environment, 314, 107346.

Gurmessa, Biyensa. (2021). Soil acidity challenges and the significance of liming and organic amendments in tropical agricultural lands with reference to Ethiopia. Environment, Development and Sustainability, 23(1), 77-99.

HUTAHAEAN, ADVEN. (2022). PENGARUH PUPUK KANDANG AYAM DAN KASCING TERHADAP PERTUMBUHAN DAN PRODUKSI TANAMAN SAWI (Brassica juncea L.) PADA TANAH ULTISOL.

Ifansyah, M. Noor, Himmah, Elok Faiqotul, \& Pertiwi, Melinda Restu. (2021). Complementary Therapies to Improve the Quality of Sleep in the Elderly: A Systematic Review. D'Nursing and Health Journal (DNHJ), 2(1), 11-16.

Menino, Regina, Felizes, Fernando, Castelo-Branco, Maria Amélia, Fareleira, Paula, Moreira, Olga, Nunes, Rui, \& Murta, Daniel. (2021). Agricultural value of Black Soldier Fly larvae frass as organic fertilizer on ryegrass. Heliyon, 7(1), e05855.

Momesso, Letusa, Crusciol, Carlos A. C., Soratto, Rogerio P., Tanaka, Katiuca S., Costa, Claudio H. M., Cantarella, Heitor, \& Kuramae, Eiko E. (2020). Upland rice yield enhanced by early nitrogen fertilization on previous palisade grass. Nutrient Cycling in Agroecosystems, 118(2), 115-131.

Mukhlisah, A. N., Abustam, E., \& Maruddin, F. (2020). The effect from different level of Melinjo (Gnetum gnemon Linn) leaf extract and storage duration on the quality of duck eggs. IOP Conference Series: Earth and Environmental Science, 492(1), 12052. IOP Publishing. 
Porcar-Castell, Albert, Malenovský, Zbyněk, Magney, Troy, Van Wittenberghe, Shari, Fernández-Marín, Beatriz, Maignan, Fabienne, Zhang, Yongguang, Maseyk, Kadmiel, Atherton, Jon, \& Albert, Loren P. (2021). Chlorophyll a fluorescence illuminates a path connecting plant molecular biology to Earth-system science. Nature Plants, 7(8), 998-1009.

Prabowo, Rossi, \& Subantoro, Renan. (2018). Analisis tanah sebagai indikator tingkat kesuburan lahan budidaya pertanian di Kota Semarang. Cendekia Eksakta, 2(2).

Pujawati, Intan, Suryanegara, Ellen, \& Rudiastuti, Aninda W. (2020). Spatial dynamics of agricultural land in Banyuasin Regency, South Sumatera: Its opportunities and threats. E3S Web of Conferences, 211, 4003. EDP Sciences.

Rochayati, Erma. (2018). Ilmu astronomi di dunia islam abad 11-15 M. UIN Sunan Ampel Surabaya.

Saputra, F., Anggraeni, A., Ishak, A. B. L., Hafid, A., Rusdin, M., \& Sumantri, C. (2021). Haplotype Diversity of Swamp Buffalo and River Buffalo Based on Cytochrome B Gene: A Study of Meta-Analysis. Tropical Animal Science Journal, 44(4), 399-407.

Sirohiwal, Abhishek, Neese, Frank, \& Pantazis, Dimitrios A. (2021). Chlorophyll excitation energies and structural stability of the CP47 antenna of photosystem II: a case study in the first-principles simulation of light-harvesting complexes. Chemical Science, 12(12), 4463-4476.

Sofyan, E. T., Sara, D. S., \& Machfud, Y. (2019). The effect of organic and inorganic fertilizer applications on N, P-uptake, K-uptake and yield of sweet corn (Zea mays saccharata Sturt). IOP Conference Series: Earth and Environmental Science, 393(1), 12021. IOP Publishing. 